\title{
Reforms to the Market for Audit and Assurance Services in the period after the Global Financial Crisis: Evidence from the UK.
}

\begin{abstract}
There was little effect by the Global Financial Crisis (GFC) on audit practices in Australia, as the country was largely sheltered from the GFC. The U.K. and Europe which had experienced significant reforms to audit were not sheltered from the GFC and regulators and law makers were pressured to take further action. The key UK and European audit reforms included the expanded auditors' report, disclosures on materiality thresholds, restrictions on non-audit services, more powers for audit committees and mandatory firm rotation by auditors. The aim of this exploratory research study is to obtain the views of relevant stakeholders in relation to the benefits and costs of the recent UK audit reforms and the new EU Audit Directive (July 2016), and via a synthesis of these results and a review of the relevant Australian accounting literature, consider whether there is scope for Australia to adopt similar reforms to audit services. The study finds there are significant reforms to auditing that have benefited the UK audit profession, and an open debate in Australia needs to be considered regarding the need for similar reforms. The study suggests a need for a proactive approach to audit reform and this lends support to recent findings from Australian accounting research studies.
\end{abstract}

Keywords: Audit reforms, audit and assurance markets, regulations.

Classification: Research paper. 


\section{INTRODUCTION}

After the major corporate collapses of early 2000s, and the Global Financial Crisis (GFC) in the period 2007-2008, the U.K. began reforming its corporate governance and audit regime. Concerns regarding the perceived lack of competition in the market for audit and assurance services in the U.K. has been widely publicised in the popular press on many occasions over many years and it has been an issue of regulatory enquiry (Oxera 2006; FRC 2007, 2009, 2010; House of Lords 2011). The Office of Fair Trading (OFT) in the U.K. decided that competition problems in the audit market warrant a referral to the U.K. Competition Commission (OFT 115-11, October 2011). The U.K. Competition Commission released its report before the end of 2013 for implementation.

During this same time the EU Commission also investigated the same issues and released the new EU Audit Directive for implementation by all member states in July 2016. Those new EU audit reforms are expected to have significant impact in many European countries. However in the UK, due to FRC's proactive approach, many of the EU changes were already in effect, hence it is expected that the impact of the new EU changes will be more limited than would otherwise have been the case in the UK market. Therefore to understand the impact of the audit reforms in the UK, we consider in this paper both the earlier UK reforms and the more recent EU audit reforms. Australia on the over hand has not experienced wide ranging legislative reforms to the audit and assurance market for more than ten years now, and in the Australian context the longer the period of no change, reform or proactive action, the greater perhaps the probability of some sort of regulatory failure in auditing. 
The broad objective of the study is to address the question "What have been some of the benefits and costs of the post-GFC reforms to audit in the UK and new EU Audit Directive, and could Australia benefit by adopting similar reforms?"

The aim of the study is to examine the benefits and costs of the new EU audit regulations and whether or not there is scope and benefits for Australia to also further reform its regulations related to audit and assurance services. Views where obtained from relevant stakeholders in the UK. Australia has not seen major legislative reform to audit since 2004, although in the 2016-17 financial period auditors will now have to report on Key Audit Matters (KAM). It is expected that this current study through a review of recent Australian accounting literature, and an analysis of the responses by the UK-based participants, will further provide some evidence that Australia may need to consider further audit reforms thus supporting findings of recent studies such as Houghton, Jubb, \& Kend (2011), Kend, Houghton, \& Jubb (2014) and Hossain and Chapple (2015). The results and discussion are drawn from a synthesis of approaches to investigate the topic. Given Australia will soon experience some minor reforms to audit and assurance services (i.e. reporting Key Audit Matters and changes to Going Concern terminology) it should be important for practitioners, regulators and academics to know if Australia is lagging behind other countries, in terms of reforming its audit and assurance services market.

Findings of this study will help regulators, academics and business professionals better understand the impact of the latest reforms to audit and assurance services on the accounting profession in the U.K. and also specifically, to start discussion on the value to the Australian audit and assurance market of following a similar path of 
reform. Any contribution to the debate on auditors' reforms and lessons from reforms to the corporate governance regime in the wake of the corporate collapses of the early 2000s for periods of serious economic distress can be valuable.

In the next section, we provide a review of prior research, as well as the necessary contextual background. The description of the sample and research methodology adopted in the study is then presented, including a discussion of the study's research questions. This is followed by an analysis of the findings. The final part of the paper concludes and discusses the implication of the research including limitations.

\section{LITERATURE REVIEW AND CONTEXTUAL BACKGROUND}

In Australia the regulatory reforms that followed the corporate failures of the early 2000's are referred to as CLERP 9 reforms. These audit and audit-related reforms are designed to enhance auditor oversight, monitoring and independence. Australia's regulation of the auditor-client relationship was reinforced in 2004 with the enactment of these CLERP 9 reforms. The CLERP 9 reforms amended the Corporation Act 2001 with a raft of changes and new regulation with the main objective being to strengthen corporate governance and auditor independence in Australia. The CLERP 9 amendments include: a general requirement of auditor independence; a requirement that auditors provide directors with an annual independence declaration; and a prohibition of a number of specific employment and financial relationships between auditors and their clients (Crockett and Ali 2015). 
In the aftermath of Enron and the collapse of Arthur Andersen, new "independent" institutions were created in different jurisdictions to oversee financial statement auditing (Malsch and Gendron 2011). The Australian Securities \& Investments Commission (ASIC) commenced its audit inspection program in 2004-05. This threat of random inspection has led the accounting firms locally to over-document their audit files which have led to changes in the auditors' work (Houghton et al. 2013). Some studies have been undertaken in other jurisdictions. For example, Malsch and Gendron (2011) investigate how the creation of the Canadian Public Accountability Board $(\mathrm{CPAB})$ has affected the dynamics of power among the main players in Canada's regulation of public accounting. Academic researchers in Australia (e.g., Houghton et al. 2010) and in the U.S. (e.g. DeFond and Francis 2005, among others) have called for evidence on whether major changes in the monitoring of accounting firms, such as these, have improved their audit quality.

An Australian study by Houghton, Jubb and Kend (2011) has found stakeholders perceive that the concepts involved in audit materiality are not well understood and they point to the difficulty in providing educative materiality about it, especially in relation to qualitative materiality, to retail investors in particular. Their study has found mixed views as to whether the actual level of tolerable error, as per one of the meanings of materiality in the audit space, should be disclosed, with some feeling that it might be detrimental or dangerous. In 2013, the UK's recent revision of ISA (UK and Ireland) 700 (ISA (UK\&I) 700) requires auditors to report how they applied the concept of materiality in performing the audit and how this affected the scope of their audit. A key objective of the reform was to promote an enhanced understanding by 
auditors, Audit Committees and investors of the judgments that need to be exercised in determining materiality levels and in applying them during the audit.

A key part of the auditor independence reforms in Australia was that CLERP 9 mandates audit partner rotation. The change was criticised predominantly due to the costs imposed on both the audit firms and the audit clients. Hossain and Chapple (2015) examine the Australian experience post-CLERP 9 with mandated auditor rotation. Based on data of audit partner rotation over 2003-2009 (on average 1200 listed Australian companies over the sample period), they show that audit partner tenure sat at a median of 2-3 years. The interesting result is that for $15 \%$ of the market, the mandated audit partner rotation had a significant impact on corporate governance practice. There is also a greater observed impact of mandatory rotation on audit engagements involving the non-global auditing firms. These findings informed the debate as to the 'costliness' of the law reform.

Another Australian study by Houghton, Jubb, Kend and Ng (2010) has provided insights on the regulatory expectations gap in auditing - the gap in expectations between the regulated and the regulator. The gap between the two can be seen as a regulatory expectations gap where the parties all possess a similar, sophisticated level of understanding of the field of practice (i.e. auditing), yet have divergent views of the need for and impact of regulation. This is unlike the more traditional expectations gap literature which emphasises difference in understanding between users of the audit product and suppliers of that product (Houghton, Kend and Jubb 2013). This concern is further addressed in the current study, by examining the UK context. 
In Australia the regulatory reforms that followed the corporate failures of the early 2000's are referred to as CLERP 9 reforms. These audit and audit-related reforms are designed to enhance auditor oversight, monitoring and independence. They were enacted after consideration of the Ramsay (2001) and HIH Royal Commission (2003) reports. The accounting profession had opportunities to examine and be consulted on these reports before the Federal Government enacted the CLERP 9 reforms (Jubb and Houghton 2007). Most recently the Australian Federal Treasury released a report in March 2010 'Audit Quality in Australia: A Strategic Review', highlighting its view that Australia's audit regulation framework is robust and stable, is a key driver of audit quality, and can be considered to be in line with international best practice. However, in the last 7 years Australia has seen no major reforms or reviews of audit regulations or practices, yet other countries had experienced major reforms, not yet considered in Australia.

In the UK and Europe there have been horizontal measures apply to all statutory auditors and audit firms, regardless of whether the audited entity is a public-interest entity (PIE) or not. The new EU Regulation (2016) establishes specific requirements regarding statutory audit of PIEs. The new rules follow an extensive consultation process which started with the EU Commission's Green Paper on Audit Policy in October 2010 and resulted in the presentation of two Commission proposals in November 2011. The stricter requirements that apply to the statutory audit of PIEs are: 
- Strengthening the requirements on the audit report, and introducing an additional, more detailed, report to the audit committee, containing thorough information about the performance of the audit;

- Introducing mandatory rotation of statutory auditors and audit firms;

- Establishing a list of non-audit services that cannot be provided by the statutory auditor or audit firm to the audited entity;

- Imposing limitations on the fees charged for non-audit services; and

- Enhancing the role and competences of the audit committee, giving it a prominent direct role in the appointment of the statutory auditor or the audit firm, as well as in the monitoring of the audit.

\section{SAMPLE AND RESEARCH METHOD}

The full sample was drawn from participants attending research workshops run in London during the second half of 2016. They included financial market regulators and audit partners from Big Four and non-Big Four accounting firms. Face to face semistructured interviews were also conducted in London with financial market regulators, accounting standard setters, non-Big Four auditors, and FTSE listed company directors. Some of the participants could be described as key players in the reforms to audit in the UK. All participants had over 15 years relevant experience. Participant's background details are all contained in table one. The workshops or office interviews each lasted approximately one and a half hours. The face to face interviews provided an opportunity to probe issues in more depth, providing a "richness" to the data that 
could not be accomplished solely through other data collection mechanisms such as hand delivered questionnaires and mail out surveys. Workshops and interviews were all audio recorded to capture the detail of the discussions. Appropriate research ethics approval was obtained from the two universities involved.

\section{[INSERT TABLE ONE]}

The main findings indicate successful audit reforms have been embraced by the accounting profession and regulatory bodies. This created further interest in understanding the specific benefits and costs of these audit reforms and whether Australia would benefit from further reforms to its audit and assurance services through academic research. Australia had not seen major reforms to audit since 2004, although in 2012 an amendment to the audit requirements in the Corporations Law was passed in Federal Parliament (Corporations Legislation Amendment (Audit Enhancement) Act 2012. No. 72, 2012). The study does not focus on audit and assurance market competition concerns as studies in Australia (Hamilton, Li and Stokes 2008; and Kend, Houghton and Jubb 2014) found that post the Arthur Andersen collapse competition concerns are not such an issue in an Australian context. So the research questions developed for this study are:

$R Q_{1}:$ What have been some of the benefits and costs of the post-GFC reforms to audit in the UK and the new EU Audit Directive?

$R Q_{2}$ : What scope and benefits (if any) are there for Australia to adopt similar reforms to audit and assurance services? 
Using thematic analysis involves six main steps, including familiarizing yourself with your data, generating initial codes, searching for themes, reviewing themes, defining and naming themes and producing the report (Braun \& Clarke 2006). Thematic analysis (Boyatzis 1998) is used to draw and verify conclusions. Initial codes on the general areas of investigation are developed before the workshops or interviews commenced and these codes were refined as the interviews, and then workshops started and progressed. This approach allowed us to start to code interviews from the early stages and to increase the trace ability and verification of the analysis. The process of coding the qualitative information involved listing themes and identifying patterns that causally relate themes and assist in describing and organizing the interview observations. Adding evidence to confirm a pattern, and being open to evidence that contradicts it, is important in forming the analysis and conclusions, and this helps protect against providing unreliable evidence (Miles 1979).

Following Glaser and Strauss (1967) and Boyatzis (1998) suggestions, the techniques of coding, memo-writing, and diagramming were employed simultaneously throughout the process of data collection. Although scholars such as Glaser (1978) and Strauss (1987) acknowledge that this approach can be painstaking, and time consuming, they recommend persistence with it. For such an approach to coding enables the researcher to remain in tune with the participant's perception of his/her reality (Charmaz, 2000), and also minimizes the chance of missing an important pattern or trend (Glaser, 1978). Also, referring to interviewees using categorizations preserves anonymity. 
NVIVO is an example of computer-assisted qualitative data analysis software specifically designed for thematic analysis (Mills, Durepos \& Wiebe 2009). Transcribed audio recordings were coded into relevant themes and using NVIVO, textual patterns will be identified from the set of interview transcriptions produced to enable conclusions to be drawn from the trends and themes in the data in an organised manner.

\section{FINDINGS}

One of the key reforms post-GFC that the UK implemented before the EU audit directive was the new enhanced audit reports (FRC 2013). The firm PwC indicated that the new extended audit reports were enhancing the understanding of audit and confidence in financial statements (PwC 2016). The participants in our workshops and interviews also expressed similar views.

One UK regulator stated: "The extended audit report allows for innovation and the auditors have the opportunity to convey more detail about their work, so they can now better indicate how they add value. It is difficult to measure if this improves audit quality, but if investors value it, then we can state it does improve audit quality. ......Around business risks there's more information out there now because of the enhanced audit reports."

A Big four partner conveyed: "Is the quality of the audit work increasing due to the extended auditor's report? That's not the case. The audit report gives more insights on 
judgments, etc and helps build confidence in the audit, but does it??? give some sense on the complexity of the audit, not always."

One audit committee chair, added the following: "I think there is enough information now in the audit reports. However too much focus is on auditor reports, when more focus should be on the audit committee report."

In relation to enhanced auditors' reports there is limited research or inconsistent results (Bedard, Coram, Espahbodi, and Mock 2016), so more research is needed. Well beyond the GFC period auditors' reports in Australia and New Zealand were highlighting going concern issues indicating a prolonged period of economic uncertainty (Carson, Fargher and Zhang 2016). Researchers have called for meaningful ways of contrasting Australia with the US or Europe as a basis for understanding the issue of going concern and how this can be standardised in the longer form auditor reports, and be meaningful. In the study by Houghton et al. (2011) some of the more experienced and sophisticated interviewees were strongly of the view that better communication of materiality is an area where action can and should be taken in Australia. This view was shared by the participants in the current UK study who embraced that reform. The disclosure of materiality thresholds was also considered very useful for investors and participants from the accounting profession who all spoke highly of this UK reform. One Big Four partner stated:

"The disclosure of materiality levels has done more to narrow the audit expectations gap than any other audit reform in recent times." 
In the UK directors of listed companies with accounting periods beginning on or after 1 October 2014 were required to convey their first viability statement - a new requirement of the UK Corporate Governance Code, in their 2015 annual report. Although this is more a reform to financial reporting than audits, this requirement does have implications for auditors and their work. The specific challenges for Boards of this new requirement has been deciding on the appropriate period to cover. The findings from the current study is that an outlook between 3-5 years has been adopted. This requirement now forces companies to think about principal risks to viability i.e., risks that could 'kill' the company, as opposed to risks to strategy that are more traditionally disclosed (EY 2015). The traditional going concern assessment typically covers up to 18 months, and post-GFC in the UK there was a view by market participants and investors that this was not sufficient. In relation to this reform the interview and workshop participants revealed the following.

A standard setter remarked: "Post-GFC the going concern issues got our attention. We created the requirement for a viability statement in the non-financial data sections of the annual reports. Auditors now have to refer to these statements and then further comment on them. This has helped better inform investors of the business risks that companies experience."

An audit committee chair commented: "Yes I think viability statements are a good initiative as it is good to look further out as going concern statements only cover up to 18 months. ......Across the business cycle would have made more sense, but the 
wording of the regulations or code forces corporate boards to look at 3-5 years not up to 10 years."

In Europe there is now a mandatory 10-year audit firm rotation for Public Interest Entities (PIEs). A maximum further 10 years can be extended up to 20 years where a public tendering process is conducted (ICAEW 2016). For joint audit arrangements a further maximum 14 years is allowed, up to 24 years (ICAEW 2016). Some countries may retain a shorter rotation period, for example Italy will remain on the 9 year rotation requirement. Australia has retained the partner rotation requirement of 5 years since CLERP 9 was implemented in 2004, although there were amendments to this requirement via the Corporations Act (Audit Enhancement) Amendment Bill in 2012. Overall our workshop and interview participants responded positively to the UK and EU rotation requirements, although diversity between EU member states was a concern.

A standard setter responded: " A major issue is the firm rotation requirement, as in the UK it's now 10 years for the public tendering requirement however firm rotation after 20 years if there was no change at the public tendering stage. ..... In some limited cases where you have a subsidiary that is considered a PIE and it operates in a country with a 10 year not the 20 year rotation requirement, then the company must decide, does it at the ten year stage and rotate the parent company's auditor too, or just rotate for the subsidiaries. This international diversity is not very helpful. 
An audit committee chair conveyed: "We landed in a good place, 20 years is long enough, tendering after 10 years is good to avoid getting too comfortable, audit tenders were rare and now a lot of effort has gone into audit tenders, but it is too early to say if audit quality has improved. If it helps firms compete against each other, then that's a good thing."

A UK regulator stated: "The tender process changes the situation and after 10 years most audits will see a change in auditor I think. So this has created more competition between auditors. Improving independence is very important."

Participants in this research study were also asked if the EU restrictions on non-audit services (NAS) would open up the market to a wider group of firms and perhaps increase competition. Up until this point the UK did not have such tight restriction on NAS as implemented by the EU audit directive, so out of all the EU reforms discussed in this paper, this was perhaps the one that would perhaps most impact the UK in terms of change. The responses in relation to NAS questioned whether such restrictions were even required, however in general the view was that the change will open the market up to a wider group of firms.

A standard setter commented: "We have seen a fall in the supply of non-audit services. In the FTSE100 they (NAS fees) are down to $30 \%$ of audit fees from $80 \%$ at its peak (4 times the audit fee). The big issue is more about perception. The EU goes further for PIEs but there are some let outs. Not much choice of other NAS providers, so some practical issues." 
A non-Big Four auditor stated: "Would non-big 4 firms bid and win NAS work? Not sure depends on how many firms bid and are invited to bid by client companies. Some providers might be prohibited to bid due to NAS provisions. So it might open the door up to other non big 4 auditors. So it opens opportunities, but it depends on audit committees and whether they want to try a non-Big 4 firm and if investors display demand for them."

An audit committee chair conveyed: "It's not our job as audit committee chairs to write the wrongs of the past like the gap between the Big four and the others. When approaching a tender you need to be wary of what the other Big 4 are providing as NAS to that client. So we might have to look at a non Big 4 given the restrictions. Shareholder pressure was reducing NAS work by the auditors anyway, so these restrictions in law were not that necessary as other mechanisms were working in my view."

Another non-Big four auditor claimed: "Over a period of time, and with the FRC introduction of tendering, rotation and greater NAS scrutiny, that created changes and forced audit committees to think differently. So in the non-Big Four space we have seen growth more in NAS than audits. So people are forced to think about a boarder range of suppliers due to these EU changes."

Whether NAS provision in Australia needs to be more tightly regulated will surely be debated for some time. Not all of our respondents were convinced the strict NAS provisions in the EU were necessary. The purpose of the Crockett and Ali (2015) 
study was to examine the efficacy of the current legislative provisions that protect auditor independence in Australia. That study poses the question: do non-audit service fees influence the level of accounting conservatism? Their empirical results demonstrated that the combination of intrinsic market mechanisms and regulation in Australia sufficiently protects auditor independence. Other respondents from the current study added that the effectiveness of the EU NAS provisions is unknown at this stage.

A Big four audit partner mentioned: "To me it depends, and the jury is still out on the competition outcome. It is early days to say if a wider group of firms will get more $N A S$. If this EU reform is to increase competition or audit quality, well it will depend on who you speak to, opinions might vary."

In relation to concerns raised by research studies such as Houghton et al. (2010) in regards to the regulatory expectations gap in Australia, and then contrasting this with the UK, the main difference appears to be the operations and structure of ASIC, versus the operations or roles of the FRC in the UK. While in Australia ASIC monitors and enforces auditor independence provisions and related regulations, in the UK the FRC's role includes oversight on the standard setting process and also the corporate governance code. Naturally there will be slight differences in the institutional environment, however because Australia and the UK have a shared heritage and there are many Top 200 listed companies from each country operating in each other's region, a comparison of the institutional settings reveals that they are not that dissimilar. However, the communication approaches of the regulators in both countries appear to be quite different. The FRC in the UK adopted a more 
consultative approach through conducting regular surveys, releasing bulletins on regulatory updates, etc. In general it appears there is better communications between the regulators in the UK and the auditing profession, than in the Australia context. Some of the comments from participants that follow explain why.

One UK regulator stated: "The FRC in the UK has responsibility for standard setting in accounting and audit, monitoring and also the corporate governance code, so the FRC is in a unique situation in the world. It gives the FRC an advantage, a more holistic view. No other regulator in the world is in this place in terms of activity or functions."

Another UK regulator conveyed: "The corporate governance reforms in the UK in 2012 brought more emphasis on audit committees. Having input and oversight on the corporate governance code makes things easier for the FRC to make the necessary changes, like tackling the going concern issues."

A non-Big Four partner added: "...in terms of what the GFC did, you cannot just focus on audit issues, what are the other issues, i.e. the audit committees role, the financial reporting issues. The going concern issue could be solved by the FRC due to its unique roles."

The Australian study by Houghton, Kend and Jubb (2013) has reported that suppliers of audit and assurance services made negative comments about the increasing 
regulation of audit and this indicates evidence of resistance to the change enforced upon the auditing profession in Australia. The suppliers all highlighted the merit of the disciplined approach to audit documentation that is now in place, however, they lament the amount of time it takes. There is an indication of discomfort and even some resistance to the past Australian reforms rather a welcoming acceptance, and further evidence of the cost impacts of these reforms, thus contributing to the auditing literature that has called for research that assists in assessing the impact of regulatory interventions on auditor behaviour (Houghton et al. 2013).

\section{RECOMMENDATIONS AND LIMITATIONS}

This research study reports findings on the most recent regulatory reforms to audit in the UK and Europe. Also this study provides a brief review of relevant Australian research studies that have focused on audit reforms. Through this synthesis of approaches we seek to explain and recognize some of the significant changes in the auditors' working environment that have arisen due to these reforms.

There are many lessons that can be learned. One needs to look at the wider picture to understand the problems that manifest themselves within the auditing profession. This paper reports findings arising from workshops and face to face office semi-structured interviews with individuals representing identified groups of stakeholders in the market for audit and assurance services in the UK. Also through a review of the Australian literature, we identify there has been reported discontent with audit regulatory change in Australia, that is perhaps dictating to auditors what they should or should not be doing within their own judgment domain and their professional tasks 
(Houghton et al. 2013). In a U.S. context, similar concern has been made that PCAOB inspectors are overly critical in second-guessing auditors' judgments (Farrell and Shabad 2005).

Overall the findings reported in this exploratory study indicate positive perceptions regarding the audit reforms in the UK and the EU. The extended auditors report for instance offers auditors an opportunity to better explain their audit judgments and the disclosure of materiality thresholds has helped, in the views of some participants, narrow the audit expectations gap. Concerns around the auditors' going concern assessments have been addressed with the implementation of viability statements, and auditor independence concerns have further been addressed with the EU decision to rotate audit firms and restrict the provision of non audit services (NAS). These audit independence reforms have been perceived as also opening up the audit and assurance market to being more competitive. Finally the various roles and operations of the FRC in the UK, enable it to have a more holistic view of the accounting profession, thus ensuring it has been an influential policy maker in the EU audit market, and the participants highlight how well the UK regulator communicates and remains transparent with accounting profession in the UK.

This current exploratory study makes the following recommendations for corporate and audit reform in Australia for policy makers to consider:

1) Australia should consider the extended auditors' report to allow auditors more scope to explain their work, and judgements; 
2) Australian audit reports should contain disclosures of materiality thresholds considered useful for shareholders and potential investors;

3) Boards in Australia should disclose viability statements in their annual reports, with an outlook between 3-5 years consistent with the UK reforms, and auditors are to review and report on these statements;

4) Australia to consider mandatory firm rotation up to 20 years, with a compulsory public tendering required within the first ten years;

5) Consider a 70\% cap on non-audit services of total group level audit fees, and other restrictions on such services, to open up the market to a wider group of firms and therefore promote more competition in the market for audit and assurance services; and

6) finally, reconsider expanding the role and function of ASIC to include standard setting oversight, monitoring, enforcement and direct input and oversight over corporate governance of listed companies.

This study has implications for other jurisdictions that now have independent institutions that oversee financial auditing, such as the CPAB in Canada and the PCAOB in the United States. Just like ASIC in Australia, these institutions have affected the dynamics of power among the main players in the market for audit and assurance services (GAO 2008). These changes may lead to the forming of allegiances (Malsch and Gendron 2011) or there maybe some evidence of reform resistance (Houghton et. al. 2013). There is scope for future accounting research in other jurisdictions to investigate regulators attempts to control and supervise this globalized industry from a national and regional perspective. Further research is 
needed covering other European countries, perhaps impacted more by the EU audit directive than the UK, such as Spain and Italy, to obtain stakeholder perceptions. Also obtaining the views of stakeholders in Australia, may be helpful to convey if there is an appetite or need for further regulatory reform to audit in Australia.

As with all qualitative research of this type, several limitations exist. The judgements as to what is included and what is omitted in the paper from the workshops and interview data are subjective. The participants' views may not be representative of others in the sector and perceptions may change over time as the EU reforms become bedded down, regulators change methods of implementation and the like. The timing of the workshops and interviews, in close proximity to the introduction of the EU Audit Directive in July 2016, means that the same views may not be expressed if interviews were conducted at a more distant time period. Further, the Brexit decision in the same time period and the uncertainty that has created in the UK and in Europe might have some impact on views. This confounding of events is very difficult to unravel and may not have been well understood by some interviewees. 


\section{REFERENCES}

Bédard, J., Coram, P., Espahbodi, R. and Mock, T. 2016, 'Does Recent Academic Research Support Changes to Audit Reporting Standards?'. Accounting Horizons, 30 (2): $255-275$.

Boyatzis, R. 1998, Transforming Qualitative Information: Thematic Analysis and Code Development. Sage Publications, Inc.

Braun, V. and Clarke, V. 2006, 'Using Thematic Analysis in Psychology'. Qualitative Research in Psychology, 3 (2): 77-101.

Carson, E., Fargher, N. and Zhang, Y. 2016, 'Trends in Auditor Reporting in Australia: A Synthesis and Opportunities for Research'. Australian Accounting Review, 26 (3): 226-243.

Charmaz, K. 2000, Grounded theory objectivist and constructivist methods. In

Denzin, N.K., Lincoln, Y. (Eds.), Handbook of Qualitative Research. Thousand Oaks: Sage Publications, Inc.

Commonwealth of Australia, 2002, 'Corporate Law Economic Reform Program Proposals for Reform (CLERP): Discussion Paper No. 9. Corporate Disclosure: Strengthening the Financial Reporting Framework', September.

Commonwealth of Australia, 2010, Audit Quality in Australia: A Strategic Review, The Treasury, March. 
Corporations Legislation Amendment (Audit Enhancement) Act 2012. No. 72, 2012.

Crockett, M. and Ali, M. J. 2015, 'Auditor Independence and Accounting Conservatism: Evidence from Australia Following the Corporate Law Economic Reform Program', International Journal of Accounting \& Information Management, 23 (1): $80-104$

DeFond, M. L. and Francis, J. 2005, 'Audit Research after Sarbanes-Oxley?' Auditing: A Journal of Practice and Theory, 24 (1): 5-30.

European Commission, 2010, Consultation on audit policy - Lessons from the Crisis, October.

European Union 2014. Regulation (EU) No 537/2014 of the European parliament and of the council of 16 April 2014 on specific requirements regarding statutory audit of public-interest entities and repealing Commission Decision 2005/909/EC. Available at: http://eur-lex.europa.eu/legalcontent/EN/TXT/PDF/?uri=CELEX:32014R0537\&from=EN. Accessed 15.07.16.

EY 2015, The Viability Statement: Finding Opportunities in the New Regulatory Challenge - March 2015.

Available at: http://www.ey.com/Publication/vwLUAssets/EY-The-viabilitystatement-March-2015/\$FILE/EY-The-viability-statement-March-2015.pdf.

Accessed 06.11.16. 
FRC 2007, 'Choice in the UK Audit Market Final Report of the Market Participants

Group'. Available at: https://www.frc.org.uk/Our-Work/Publications/FRCBoard/Final-report-of-the-Market-Participants-Group-(200.pdf. Accessed 18.07.16.

FRC 2009, Choice in the UK Audit Market - Third progress report. Available at: https://www.frc.org.uk/Our-Work/Publications/FRC-Board/Choice-in-the-UK-AuditMarket-Third-Progress-Repor.pdf. Accessed 24.07.16.

FRC 2010, Submission to the House of Lords economic affairs committee: "Auditors: Market Concentration and their Role". Available at: https://www.frc.org.uk/OurWork/Publications/FRC-Board/Choice-FRC-submission-to-HOL-Inquiry.pdf. Accessed 28.06.16.

FRC 2013, Revision to ISA (UK and Ireland) 700. Available at: https://www.frc.org.uk/getattachment/d24bb652-e319-46a4-add5793d518a035b/Consultation-Paper-Revision-to-ISA-(UK-and-Ireland.aspx. Accessed 28.06.2017

General Accounting Office (GAO) 2008, Public accounting firms mandated study on consolidation and competition. Available at: http://www.gao.gov/assets/240/239226.pdf. Accessed 20.07.16.

Glaser, B. G. 1978, Theoretical Sensitivity. Mill Valley: The Sociology Press. 
Glaser, B. G. and Strauss, A. L. 1967, The Discovery of Grounded Theory. Strategies for Qualitative Research. New York: Aldine publishing Company.

Hamilton, J., Li, Y. and Stokes, D. 2008, 'Is The Audit Services Market Competitive Following Arthur Andersen's Collapse?', Accounting and Finance, 48 (2): 233.

HIH Royal Commission, 2003, The Failure of HIH Insurance, Commonwealth of Australia. Available at: http://www.hihroyalcom.gov.au/finalreport/index.htm.

Hossain, S. and Chapple, L. 2015, 'Mandatory Auditor Rotation - Australian Evidence', Australian Journal of Corporate Law, 24 (1).

Houghton, K. A. Jubb, C. Kend, M. and Ng, J. 2010, 'The Future of Audit: Keeping Capital Markets Efficient, Towards A National Strategy on the Future of Auditing', ANU E Press.

Houghton, K. Jubb, C. and Kend, M. 2011, 'Materiality in the Context of Audit: The Real Expectations Gap', Managerial Auditing Journal, 26 (6): 482.

Houghton, K. Kend, M. and Jubb, C. 2013, 'The CLERP 9 Audit Reforms: Benefits and Costs Through the Eyes of Regulators, Standard Setters and Audit Service Suppliers', ABACUS: A Journal of Accounting, Finance and Business Studies, 49 (2): 139. 
House of Lords 2011, Auditors: Market Concentration and their role Volume I:

Report. Available at:

http://www.publications.parliament.uk/pa/ld201011/ldselect/ldeconaf/119/119.pdf.

Accessed 03.07.16.

ICAEW 2016, Implementation of European Audit Reforms. Available at: http://www.icaew.com/en/technical/ethics/auditor-independence/implementation-ofeuropean-audit-reforms. Accessed 14.07.16.

ISA (UK and Ireland) 700 (Revised). 2013, The Auditor's Report on Financial Statements.

Jubb, C.A. and Houghton, K. 2007, 'The Australian Auditing and Assurance Standards Board after the implementation of CLERP 9', Australian Accounting Review, 17 (2): 18-27.

Kend, M. Houghton, K. and Jubb, C. 2014, 'Competition Issues in the Market for Audit and Assurance Services: Are the Concerns Justified?', Australian Accounting Review, 24 (4): 313-320.

Malsch, B. and Gendron, Y. 2011, 'Reining in Auditors: On the Dynamics of Power Surrounding an "innovation" in the Regulatory Space'. Accounting, Organizations and Society, 36 (7): 456-476. 
Miles, M.B. 1979, 'Qualitative Data as an Attraction Nuisance: The Problem of Analysis'. Administrative Science Quarterly, 24: 590-601.

Mills, A. Durepos, G. and Wiebe, E. 2009, Encyclopedia of Case Study Research, Sage Publications, London.

Office of Fair Trading. Press Release 115-11. 2011, OFT Refers Audit Market to Competition Commission. United Kingdom. $21^{\text {st }}$ October.

Oxera 2006, Competition and Choice in the UK Audit Market. Available at: http://www.oxera.com/getmedia/6f57bebe-ad07-4e01-953f-687f170319d2/Competition-andchoice-in-the-UK-audit-market\%E2\%80\%94executive-summary 1.pdf.aspx. Accessed 20.06.16.

PwC 2016, Expanded Audit Reports are a Hit, Available at: http://www.pwc.co.uk/finance/assurance/expanded-audit-reports-are-a-hit.html. Accessed 05.11.16.

Ramsay, I. 2001, Independence of Australian Company Auditors: Review of Current Australian Requirements and Proposals for Reform. Report to the Minister for Financial Services and Regulation, Australia.

Strauss, A. L. 1987, Qualitative Analysis for Social Scientists. Cambridge: Cambridge University Press.

The UK Corporate Governance Code (April 2016). 
TABLE ONE

Background Details of Participants

\begin{tabular}{|c|c|c|c|c|}
\hline Classification & $\begin{array}{l}\text { Groups of } \\
\text { respondents }\end{array}$ & $\begin{array}{l}\text { Number of } \\
\text { respondents }\end{array}$ & Age & $\begin{array}{l}\text { Years of } \\
\text { Experience }\end{array}$ \\
\hline 1 & $\begin{array}{l}\text { Financial Market } \\
\text { Regulators }\end{array}$ & $\begin{array}{l}2 \text { (1 male, } 1 \\
\text { female) }\end{array}$ & $\begin{array}{l}>55 \mathrm{yrs} \\
46-55 \mathrm{yrs}\end{array}$ & $>15 y r s$ \\
\hline 2 & $\begin{array}{l}\text { Accounting Standard } \\
\text { Setter/s }\end{array}$ & 1 (1 male) & $>55 \mathrm{yrs}$ & $>15 y r s$ \\
\hline 3 & $\begin{array}{l}\text { Audit Partner/s of } \\
\text { Big Four }\end{array}$ & 1 (1 female) & $>55 \mathrm{yrs}$ & $>15 y r s$ \\
\hline 4 & $\begin{array}{l}\text { Senior auditors of } \\
\text { the non-Big Four } \\
\text { firms }\end{array}$ & 2 (2 males) & $\begin{array}{l}\text { Both } \\
>55 y r s\end{array}$ & $>15 y r s$ \\
\hline 5 & $\begin{array}{l}\text { Chair/s of Audit } \\
\text { Committee listed } \\
\text { FTSE companies }\end{array}$ & 1 (1 male) & $>55 y r s$ & $>15 y r s$ \\
\hline Total & & 7 & & \\
\hline
\end{tabular}

